\title{
The Potential Role of Kallistatin in the Development of Abdominal Aortic Aneurysm
}

\author{
Jiaze Li ${ }^{1}$, Smriti Murali Krishna ${ }^{1}$ and Jonathan Golledge ${ }^{1,2, *}$ \\ 1 Queensland Research Centre for Peripheral Vascular Disease, College of Medicine and Dentistry, \\ James Cook University, 4811 Townsville, Australia; jiaze.li@jcu.edu.au (J.L.); smriti.krishna@jcu.edu.au (S.M.K.) \\ 2 Department of Vascular and Endovascular Surgery, The Townsville Hospital, 4811 Townsville, Australia \\ * Correspondence: jonathan.golledge@jcu.edu.au; Tel.: +61-7-4433-1417
}

Academic Editor: Shaker A. Mousa

Received: 18 July 2016; Accepted: 5 August 2016; Published: 11 August 2016

\begin{abstract}
Abdominal aortic aneurysm (AAA) is a vascular condition that causes permanent dilation of the abdominal aorta, which can lead to death due to aortic rupture. The only treatment for AAA is surgical repair, and there is no current drug treatment for AAA. Aortic inflammation, vascular smooth muscle cell apoptosis, angiogenesis, oxidative stress and vascular remodeling are implicated in AAA pathogenesis. Kallistatin is a serine proteinase inhibitor, which has been shown to have a variety of functions, potentially relevant in AAA pathogenesis. Kallistatin has been reported to have inhibitory effects on tumor necrosis factor alpha (TNF- $\alpha$ ) signaling induced oxidative stress and apoptosis. Kallistatin also inhibits vascular endothelial growth factor (VEGF) and Wnt canonical signaling, which promote inflammation, angiogenesis, and vascular remodeling in various pre-clinical experimental models. This review explores the potential protective role of kallistatin in AAA pathogenesis.
\end{abstract}

Keywords: kallistatin; serine proteinase inhibitors; abdominal aortic aneurysm; vascular remodelling; oxidative stress

\section{Introduction}

Abdominal aortic aneurysm (AAA) is usually defined as a permanent dilation of the abdominal aortic wall beyond a maximum diameter of $\geqslant 30 \mathrm{~mm}[1,2]$. Progressive AAA dilatation can lead to rupture of the aorta, which causes bleeding and commonly death. AAAs most commonly affect men aged over 65 years [3], and clinical practice lacks effective treatment other than surgical approaches to repair AAAs [4]. Patients who have small AAAs $(<55 \mathrm{~mm})$, which are at low risk of rupture, are generally monitored through imaging surveillance. Patients with large $(\geqslant 55 \mathrm{~mm})$, rapidly growing (>10 mm/year) or symptomatic AAAs usually undergo repair by open surgical techniques or endovascular stents. However, postoperative morbidity and mortality are still common [2,5].

Studies of pre-clinical AAA animal models and biopsies of large human AAAs have implicated a range of mechanisms to be involved in the pathogenesis of AAA including degradation of the aortic extracellular matrix by a range of proteolytic enzymes, such as matrix metalloproteinases (MMPs); dysfunction of aortic vascular smooth muscle cells (VSMC) associated with their loss from the aortic media through apoptosis [6-9]; and inflammatory cells infiltration into the aortic wall which once activated produce pro-inflammatory cytokines, chemokines and proteolytic enzymes, which promote cell migration and vessel remodeling [2,10-14]. Other mechanisms implicated in AAA pathogenesis include angiogenesis [15] and oxidative stress [16]. AAA is often accompanied by atherosclerosis. This is in contrast to the aneurysms observed in genetic disorders, such as Marfan and Loeys-Dietz Syndromes.

Kallistatin is a member of the serine proteinase inhibitors (SERPIN) family. In human, it is encoded by the SERPINA4 gene. It was first identified as a kallikrein binding protein that regulates the kinin-kallikrein 
pathway [17,18]. Kallikrein produces kinin from kininogens by proteolysis. Kallistatin binds to kallikrein to inhibit this process. Kallistatin has also been shown to have direct vascular effects, such as promoting vasodilation within rat models when human kallistatin is administered through gene overexpression [19]. Kallistatin is expressed in both endothelial cells (ECs) and VSMCs [20]. Kallistatin is also found in plasma, which is believed to reflect its production in the liver [17]. Decreased kallistatin levels have been previously associated with various disease conditions [21,22]. For example, Ma et al. reported decreased kallistatin level in the vitreous fluids in patients with diabetic retinopathy [21]. Zhu et al. reported decreased plasma kallistatin levels in apparently healthy African American adolescents with increased adiposity and cardio-metabolic risk [22].

Recent work has revealed potential protective functions of kallistatin in many pathophysiological processes implicated in AAA, such as inflammation [23-26], oxidative stress [25,27], angiogenesis [26,28,29], and hypertension $[19,30,31]$. The heparin binding domain of kallistatin is considered important for these functions [32-34]. Evidence from pre-clinical studies suggests that reducing inflammation [35], decreasing oxidative stress [36,37] and inhibiting angiogenesis [38] may limit AAA progression. Hence, in clinical management of AAAs, treatments targeting these mechanisms are considered to have potential benefits in managing AAAs [39]. In this review, we sought to highlight the potential regulatory roles of kallistatin in mechanisms relevant in AAA pathogenesis and also the downstream signaling pathways through which kallistatin exerts its actions.

\section{Potential Roles of Kallistatin in AAA Pathogenesis}

\subsection{Kallistatin Attenuates Oxidative Stress}

Tumor necrosis factor alpha (TNF- $\alpha$ ) is a pro-inflammatory cytokine that has been consistently reported to be upregulated in AAAs [40]. TNF- $\alpha$ signaling initiates through binding of its membrane bound receptors TNFR- 1 and 2. TNFR-2 is mainly expressed in immune cells and its functions remain unclear, while TNFR-1 initiates three major signaling pathways in cells, such as EC, as shown in Figure 1 [41,42]. Kallistatin has been shown to inhibit TNF- $\alpha$ induced oxidative stress and subsequent inflammation and apoptosis in experimental studies (Table 1) [25,27,43-45]. The inhibitory effects of kallistatin on TNF- $\alpha$ was discovered to be through competitive binding of TNF- $\alpha$ to the TNFRs through its heparin binding domain, thus inhibiting its signaling, which resulted in attenuated inflammation, oxidative stress and apoptosis of ECs [24,26,27].

Table 1. Studies showing the inhibitory effects of kallistatin mediated through blocking TNF- $\alpha$ signaling on pathologies relevant to abdominal aortic aneurysm such as oxidative stress, inflammation and apoptosis.

\begin{tabular}{cccc}
\hline Inhibited Pathology & In Vitro Model & In Vivo Model & References \\
\hline \multirow{2}{*}{$\begin{array}{c}\text { Oxidative } \\
\text { stress/inflammation }\end{array}$} & $\begin{array}{c}\text { Proximal tubular } \\
\text { cells, mesangial cells }\end{array}$ & Dahl-salt sensitive rats & {$[45]$} \\
\cline { 2 - 4 } & HUVEC & Hypertensive rats & {$[43]$} \\
\hline \multirow{nyyy}{*}{$\begin{array}{c}\text { Oxidative } \\
\text { stress/apoptosis }\end{array}$} & Rat and human endo-PC & $\begin{array}{c}\text { Deoxycorticosterone acetate } \\
\text { salt-hypertensive rats }\end{array}$ & {$[44]$} \\
\cline { 2 - 4 } & HUVEC & Rats & {$[27]$} \\
\hline
\end{tabular}

Abbreviations: endo-PC—endothelial progenitor cells; HUVEC—-human umbilical vein endothelial cells; TNF- $\alpha$-tumor necrosis factor alpha. 


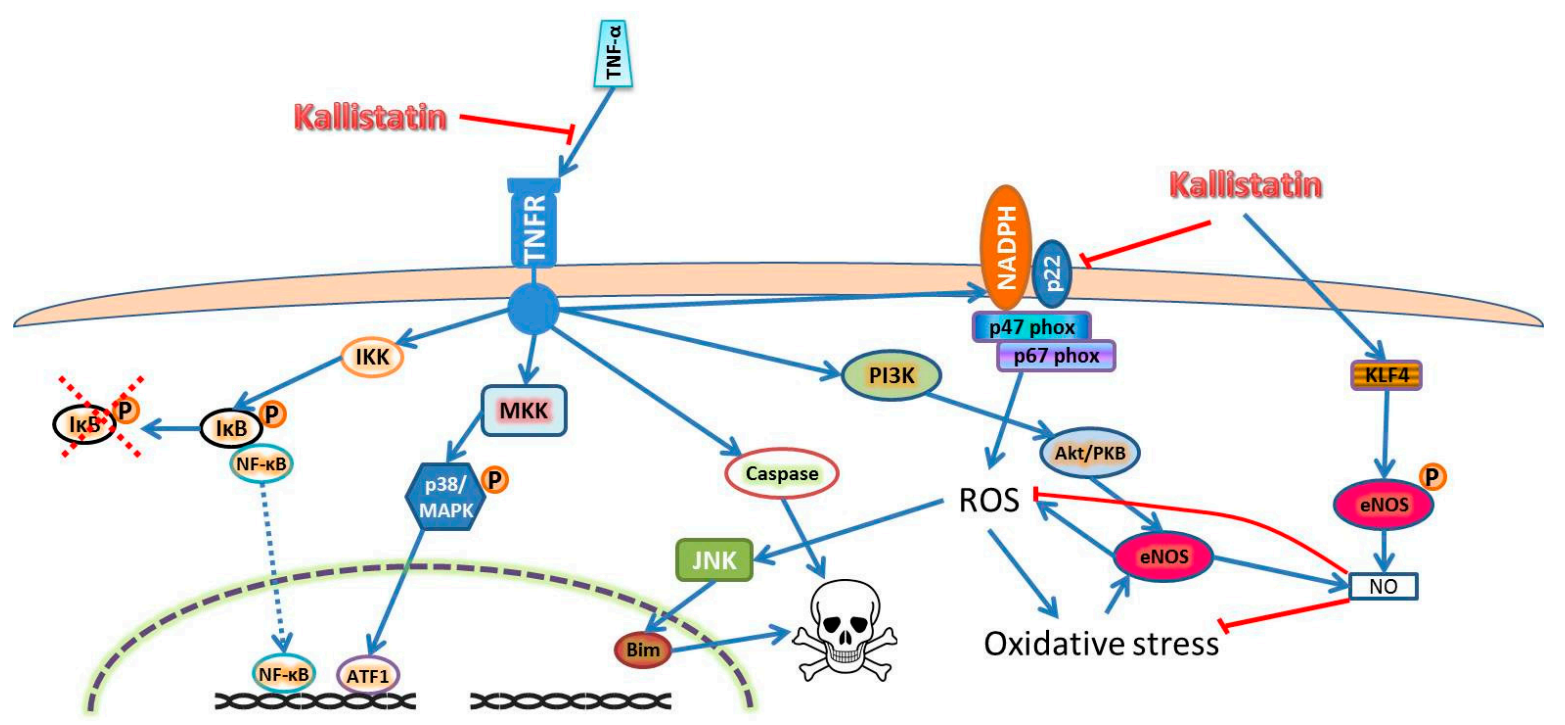

Figure 1. Kallistatin inhibits oxidative stress, inflammation and apoptosis through inhibiting TNF- $\alpha$ signaling and promotes NO production through eNOS stimulation. Kallistatin blocks TNF- $\alpha$ signaling through competitive binding to TNFR. This inhibits downstream signaling pathways that are activated by TNF- $\alpha$, such as I $\mathrm{B} / \mathrm{NF}-\kappa \mathrm{B}$ and p38 MAPK pathway, which activate many pro-inflammatory and pro-angiogenic markers, such as TNF- $\alpha$, VEGF, interleukins, MCP-1, MMPs and adhesion molecules. Kallistatin also inhibits TNF- $\alpha$ induces oxidative stress and the caspase cascade to induce apoptosis through TNFR-1. Alternatively, kallistatin is able to directly inhibit NADPH oxidase activity to attenuate ROS production, as well as activating eNOS through KLF4 to produce NO, which neutralizes ROS [43]. Abbreviations: endo-PC-endothelial progenitor cell, HUVEC-human umbilical vein endothelial cell, TNF- $\alpha$-tumor necrosis factor alpha. Abbreviations: Akt/PKB-protein kinase B; ATF1-activating transcription factor 1; Bim-Bcl2 binding protein; eNOS—endothelial

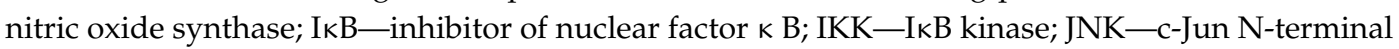
kinase; KLF4-kruppel like factor 4; MAPK—-mitogen activated protein kinase; MKK-MAPK kinase; $\mathrm{NADPH}$-nicotinamide adenine dinucleotide phosphate; NF- $\mathrm{KB}$-nuclear factor $\mathrm{\kappa B}$; NO—nitric oxide; $\mathrm{P}$ - phosphorylation; PI3K-phosphoinositide 3 kinase; ROS-reactive oxygen species; TNF- $\alpha$ - tumor necrosis factor alpha; TNFR-TNF- $\alpha$ receptor. The blue arrow lines indicate promotional activity; the red stop lines indicate inhibiting activity; the red dashed cross indicates degradation.

Oxidative stress is caused by excessive production of reactive oxygen species (ROS). The ROS signaling pathway is also known as redox signaling [46]. High level of ROS have been shown to promote apoptosis of ECs, while continuous low level of ROS promote EC proliferation and migration that promote angiogenesis $[47,48]$. Nicotinamide adenine dinucleotide phosphate (NADPH) oxidase is the main source of ROS in ECs [46]. Interestingly, redox signaling and vascular endothelial growth factor (VEGF) signaling appear to be in feedback interaction in ECs [46,49]. Numerous stimuli are able to activate NADPH oxidase in ECs including VEGF, angiopoietin-1, angiotensin II, cytokines, shear stress and hypoxia $[47,50,51]$.

There is a close relationship between oxidative stress and kallistatin activity. Oxidative stress has been shown to suppress circulating levels of kallistatin and EC specific expression of kallistatin [52,53], while kallistatin has been shown to suppress ROS production in cardiac and renal cells [45,54]. Many studies have suggested that kallistatin has anti-oxidative stress functions through inhibiting NADPH oxidase activities in various cell types, such as cardiac, epithelial progenitor cells (epi-PCs) and endothelial progenitor cells (endo-PCs), as well as in experimental models of myocardial infarction, hypertension and diabetes in rodents [44,54-56]. Furthermore, administration of anti-kallistatin antibody to rats has been reported to increase superoxide formation within the aorta and increased NADPH activity in the kidney and heart which eventually led to organ hypertrophy, inflammation 
and fibrosis. This was evidenced by a concomitant increased expression of pro-inflammatory genes such as TNF- $\alpha[25,54]$.

A study by Shen et al. reported that kallistatin attenuated aortic superoxide formation in salt induced hypertension in rats as well as inhibited TNF- $\alpha$ induced NADPH activity, oxidative stress and apoptosis through the PI3K-Akt-eNOS pathway in ECs [27]. ECs produce nitric oxide (NO) through endothelial nitric oxide synthase (eNOS), which neutralizes ROS. However, in oxidative stress conditions, the formation of peroxynitrite from superoxide and NO causes eNOS uncoupling and production of ROS $[57,58]$. ROS is known to induce apoptosis through inducing c-Jun $\mathrm{NH}_{2}$-terminal kinase (JNK) mediated Bim (a Bcl2 binding protein) nuclear translocation [53]. In an alternative pathway, kallistatin induces NO production through kruppel like factor-4 (KLF4) mediated eNOS activation and expression [43]. Thus, the switch of eNOS to produce NO by kallistatin stimulation inhibits ROS induced JNK-Bim mediated apoptosis [27]. Since ROS and cell apoptosis are implicated in AAA, stimulating kallistatin to upregulate NO production and limit cell apoptosis could be a potential target for therapy for AAA (Figure 1) [19,24,26,27,42-44,54,56,59-64].

\subsection{Kallistatin Attenuates Angiogenesis and Inflammation}

A previous study has shown that AAAs is associated with a marked angiogenic response directly related to the extent of inflammation within the aortic wall [65]. In this process, ECs proliferate and produce inflammatory cytokines, chemokines and MMPs. This initiates an influx of inflammatory cells which produce more cytokines, chemokines and MMPs that foster further endothelial activation, proliferation and inflammatory cell recruitment [66-71]. Upregulation of pro-angiogenic cytokines and medial neovascularization have been reported at the site of AAA rupture in human samples suggesting that angiogenesis plays an important role in AAA rupture [72]. VEGF is the most well-known and potent pro-angiogenic factor, especially the VEGF-A isoform [73-77]. There are three VEGF receptors-1, 2 and 3, identified so far. Among them, the type 2 receptor, VEGFR-2, which is also known as kinase insert domain receptor (KDR), a type III receptor tyrosine kinase, is the one that mediates downstream signaling of VEGF-A to induce EC activation and proliferation and promote angiogenesis (Figure 2) [29,32,44,46,48,54,56,77-99].

Kallistatin had been shown to inhibit VEGF signaling within in vitro studies. Huang and colleagues showed that recombinant human kallistatin inhibited VEGF165 mediated tyrosine phosphorylation of VEGFR-2 in human umbilical vein endothelial cells (HUVECs). Furthermore, it was also shown that the kallistatin mediated inhibition of VEGFR-2 was also accompanied by reduced downstream Akt and ERK phosphorylation [29]. The study reported by Miao and colleagues provided direct evidence of the ability of kallistatin to inhibit VEGF signaling by competitive binding to a VEGF receptor in human dermal microvascular endothelial cells (HDMECs). Using a site directed mutant of human kallistatin (K312A/K313A), they also confirmed that the heparin binding domain of kallistatin is important to this function [34].

The Wingless (Wnt) signaling pathway is a tightly regulated, highly complex system which mediates a diverse range of cellular activities including proliferation, apoptosis, migration and differentiation, all of which are relevant in AAA pathogenesis. There are 19 potential Wnt ligands that are able to bind to 10 transmembrane G-protein-coupled receptors of the Frizzled (Fzd) family [100]. The signaling pathways activated as a consequence of Wnt/Fzd binding are categorized into canonical and non-canonical pathways (Figure 3) [101-108]. In vitro experiments suggest that kallistatin inhibits the Wnt pathway at the extracellular or the receptor level. Kallistatin binds to the extracellular domain of low density lipoprotein receptor-related protein 6 (LRP6) which blocks Wnt canonical pathway signaling through $\beta$-catenin $[105,109,110]$. This has potential anti-angiogenic and anti-inflammatory effects as shown by Liu et al. in a diabetic mouse model of retinopathy [105]. It was shown that overexpression of human kallistatin in the retina of Akita mice, significantly decreased the expression of pro-angiogenic factors such as VEGF, intercellular adhesion molecule (ICAM)-1 as well as the number of $\mathrm{CD} 11^{+} \mathrm{b}$ leukocytes suggesting that overexpression of kallistatin suppressed Wnt signaling 
induced by ischemia or diabetes [105]. They also demonstrated that human kallistatin reduced VEGF and TNF- $\alpha$ levels which were increased in retinal cells treated with high glucose in culture [105]. Similar phenomenon of attenuated VEGF and TNF- $\alpha$ production by kallistatin were also observed in breast cancer and wound healing models $[110,111]$.

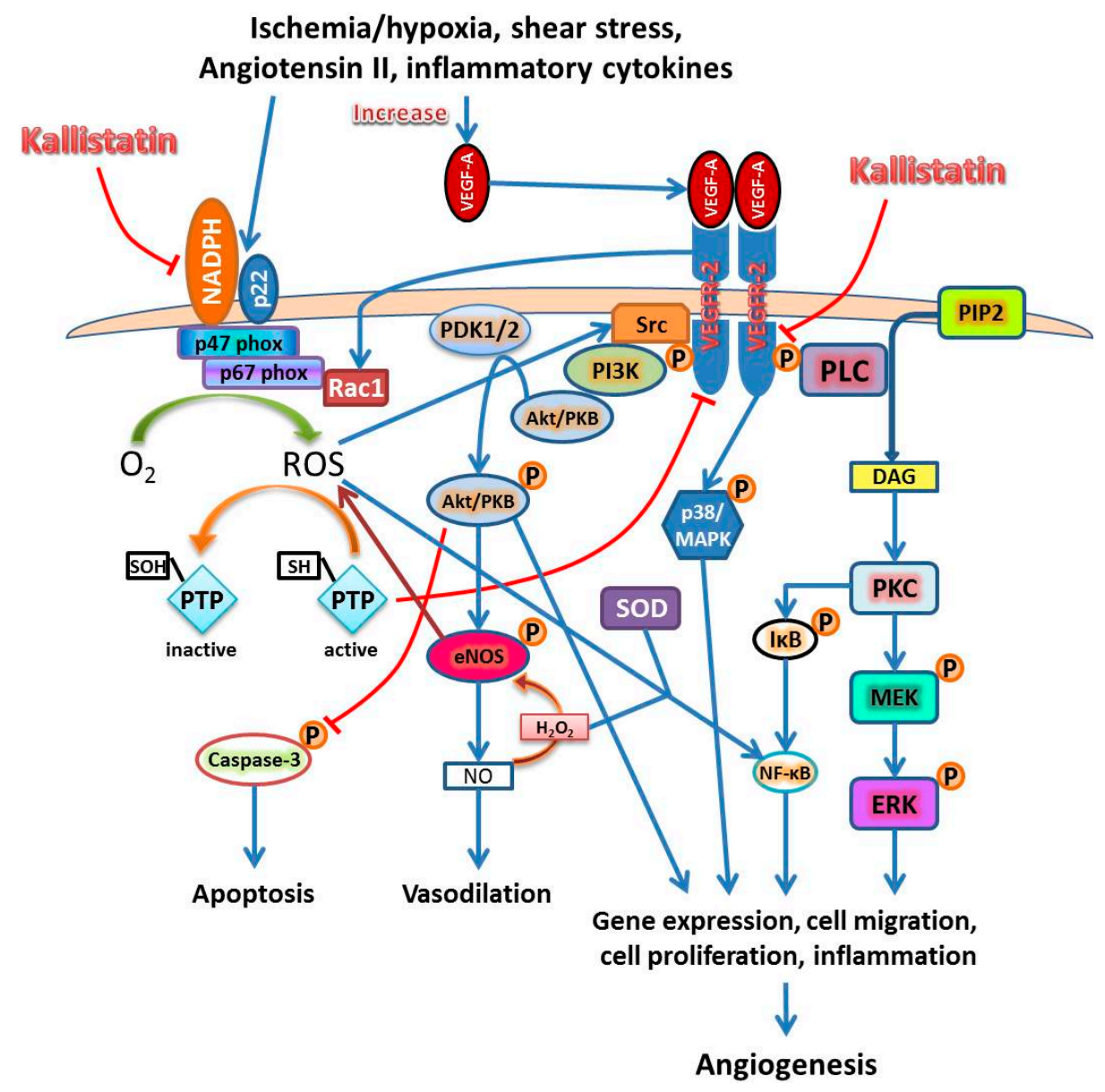

Figure 2. Kallistatin inhibits angiogenesis and inflammation through blocking VEGF signaling and NADPH oxidase activity. Kallistatin inhibits VEGF signaling through VEGFR-2 by its heparin-binding domain. VEGF-VEGFR signaling through PI3K-Akt pathway; the p38 MAPK pathway; and the PLC pathway leads to ROS/NO production, apoptosis, gene expression, cell migration, cell proliferation and inflammation. All of which are involved in angiogenesis. Kallistatin also directly inhibits NADPH oxidase activity and attenuates ROS production. NADPH oxidase is a complex consisting of several components. NADPH activity and VEGF-A/VEGFR-2 signaling have close interaction that is able to induce or activate many proangiogenic factors, such as MCP-1, VEGF, NF- kB, IL-8, VCAM-1, VE-cadherin and HIF1 $\alpha$ in endothelial cells. Abbreviations: Akt-also known as protein kinase B-PKB; DAG—diacylglycerol; ERK—extracellular signal-regulated kinase; eNOS—endothelial nitric oxide synthase; HIF1 $\alpha$ - hypoxia induced factor 1 alpha; IKB-inhibitor of nuclear factor КB; IL-8-interleukin-8; MAPK/MEK-mitogen activated protein kinase; MCP-1-monocyte chemoattractant protein-1; NADPH—nicotinamide adenine dinucleotide phosphate; NF- $\mathrm{B}$-nuclear factor $\mathrm{K} \mathrm{B}$; $\mathrm{NO}-$ nitric oxide; PDK1/2-3-phosphoinositide dependent protein kinase 1 and 2; PI3K-phosphatidylinositol-3 kinase; PIP2-phosphatidylinositol 4,5-bisphosphate; PKC-protein kinase C; PLC-phospholipase C; PTP-protein tyrosine phosphatase; Rac1-small GTPase; ROS—reactive oxygen species; SOD—manganese superoxide dismutase; Src-non-receptor tyrosine kinase; VCAM-1—vascular cell adhesion molecule-1; VE-vascular endothelial; VEGF-A—vascular endothelial growth factor-A; VEGFR-2-VEGF receptor-2. The blue arrow lines indicate promotional activity; the red stop lines indicate inhibiting activity. 


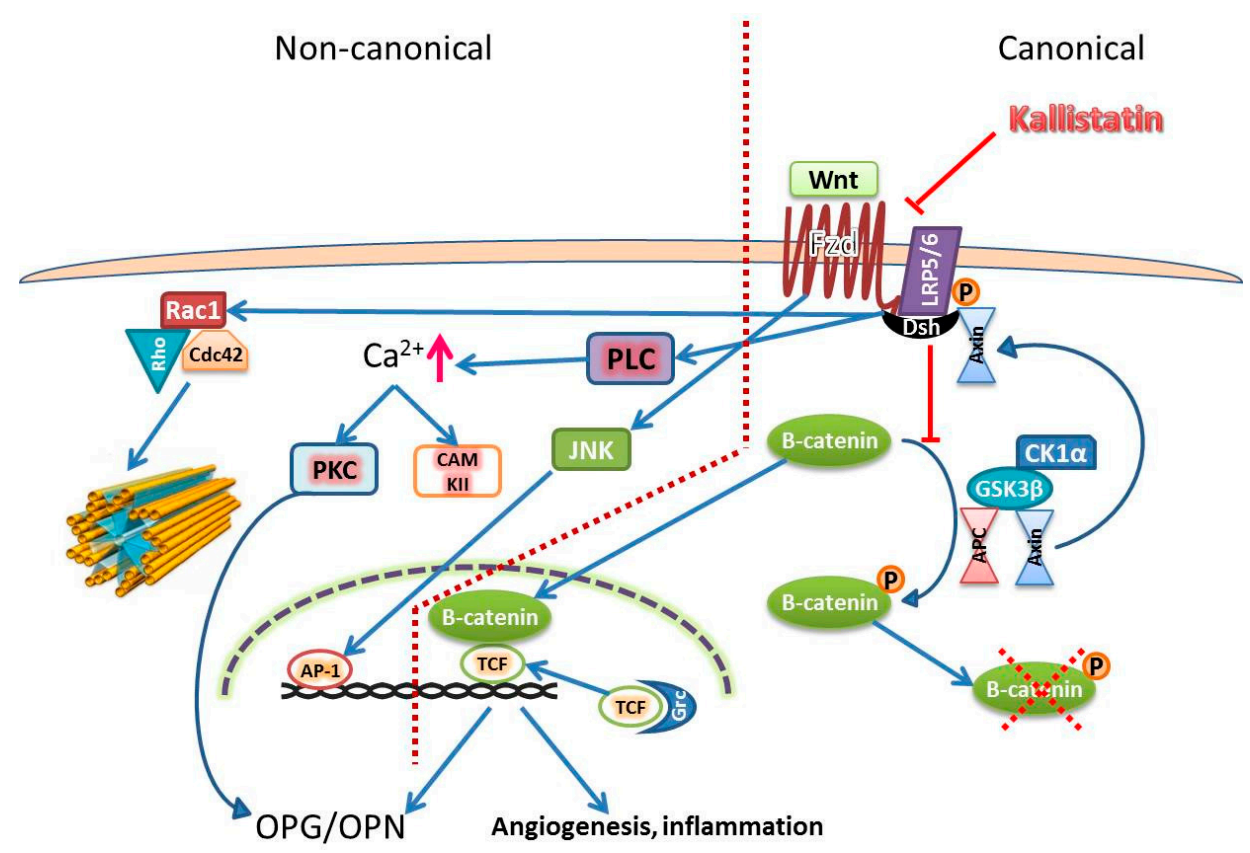

Figure 3. Kallistatin inhibits Wnt canonical pathway induced angiogenesis and inflammation. In the Wnt canonical pathways, mostly mediated by Wnt1, 3, 3a, 7a and 7b, Wnt/Fzd binding phosphorylates the associated co-receptor LRP5/6. This recruits Dsh which leads to binding of Axin at the membrane. Axin forms a degradation complex with APC, CK $1 \alpha$ and GSK $3 \beta$ for $\beta$-catenin degradation. The recruitment binding of Axin to the membrane caused by Wnt/Fzd leads to an inactive degradation complex and the accumulation of $\beta$-catenin. The accumulated $\beta$-catenin mediates Wnt signaling by activating transcription factors, such as TCF, which induces transcription of genes, such as VEGF, ICAM-1 and TNF- $\alpha$. Kallistatin binds to LRP6 and prevents LRP6 from phosphorylation which results in $\beta$-catenin degradation. Without $\beta$-catenin, Wnt canonical signaling is blocked. Abbreviation: AP-1—activator protein-1; APC—adenomatous polyposis coli; CAMKII—calmodulin dependent protein kinase; CK1 $\alpha$ —casein kinase $1 \alpha$; Dsh—the protein disheveled; GSK3 $\beta$ —glycogen synthase kinase-3 $\beta$; ICAM-1—intracellulcar adhesion molecule-1; LRP5/6-low density lipoprotein receptor-related protein 5 or 6; PCP—-planar cell polarity; OPG—osteoprotegerin; OPN—osteopontin; TCF-T-cell factor; TNF- $\alpha$ - tumor necrosis factor alpha; VEGF-vascular endothelial growth factor; the red arrow indicates increase in level; the tubular structure on the left represents cytoskeleton. The blue arrow lines indicate promotional activity; the red stop lines indicate inhibiting activity; the red dashed cross indicates degradation.

The Wnt non-canonical pathway is mostly mediated by Wnt4, 5a and 11 resulting in increased $\mathrm{Ca}^{2+}$ which activates PKC and CAMKII which often activate nuclear factor of activated T-cells that promotes VEGF induced angiogenesis. Another signaling pathway activated by the Wnt non-canonical pathway is JNK which leads to gene transcription by activating AP-1. The Wnt non-canonical pathway is also able to activate the PCP pathway which leads to cell polarization and cytoskeletal rearrangement in ECs.

A number of preclinical studies have suggested that kallistatin had anti-angiogenic functions (Table 2) [26,28,105,112,113]. In animal models of diabetes or oxygen induced retinopathy and neovascularization, administering human kallistatin to retinal cells or overexpressing human kallistatin in transgenic mice ameliorated neovascularization through inhibiting VEGF activity, endo-PC release from bone marrow and reducing activation of the Wnt canonical pathway $[105,112,113]$. The Wnt canonical pathway has been shown to stimulate EC proliferation and survival through VEGF-A upregulation [104,114]. In addition, Wang and colleagues reported that kallistatin inhibited proliferation of HDMECs and reduced vessel density in the ankles of arthritic rats through reducing 
TNF- $\alpha$ [26]. TNF- $\alpha$ was previously shown to induce the gene expressions of VEGF-A, VEGFR-2 and its co-receptor neuropilin-1 [60]. Further to this, kallistatin was shown to inhibit the Wnt canonical pathway through binding to LRP6 and inhibiting TNF- $\alpha$ in cancer cells, both of which also resulted in reduced VEGF expression $[28,110]$. Thus, it is evident that kallistatin has anti-angiogenic effects.

Table 2. Studies assessing the inhibitory effects of Kallistatin mediated through blocking VEGF, TNF- $\alpha$ and Wnt canonical signaling pathways on pathologies relevant to abdominal aortic aneurysm such as angiogenesis and inflammation.

\begin{tabular}{|c|c|c|c|c|}
\hline Inhibited Pathology & Pathways & In Vitro Model & In Vivo Model & References \\
\hline $\begin{array}{c}\text { Retinal neovascularisation/ } \\
\text { angiogenesis }\end{array}$ & VEGF & $\begin{array}{c}\text { Retinal } \\
\text { capillary ECs }\end{array}$ & Brown Norway rats & [112] \\
\hline Angiogenesis in cancer & TNF- $\alpha /$ VEGF & $\begin{array}{l}\text { MCF-7 cells, } \\
\text { HUVEC }\end{array}$ & Fertilized chicken egg & [28] \\
\hline $\begin{array}{c}\text { Angiogenesis/ } \\
\text { inflammation arthritis }\end{array}$ & TNF- $\alpha$ & HDMEC & Rats & [26] \\
\hline $\begin{array}{c}\text { Angiogenesis/Inflammation } \\
\text { Diabetic or OIR }\end{array}$ & $\begin{array}{l}\text { Wnt canonical } \\
\text { pathway }\end{array}$ & Retinal cells & $\begin{array}{l}\text { Kallistatin transgenic } \\
\text { mice with OIR or type } \\
\text { I diabetes }\end{array}$ & [105] \\
\hline $\begin{array}{l}\text { Oxygen induced } \\
\text { retinopathy/angiogenesis }\end{array}$ & $\begin{array}{l}\text { Wnt canonical } \\
\text { pathway }\end{array}$ & - & $\begin{array}{l}\text { Kallistatin transgenic } \\
\text { mice, bet-gal mice }\end{array}$ & [113] \\
\hline $\begin{array}{l}\text { Abbreviations: EC-endo } \\
\text { HUVEC-human umbilical } \\
\text { cancer cell line); OIR-oxyg } \\
\text { endothelial growth factor. }\end{array}$ & $\begin{array}{l}\text { lial cells; } \mathrm{HI} \\
\text { n endothelial c } \\
\text { nduced retinor }\end{array}$ & $\begin{array}{l}\text { C-human der } \\
\text { MCF-Michigan } \\
\text {;NF- } \alpha \text {-tumor }\end{array}$ & $\begin{array}{l}\text { microvascular endo } \\
\text { ncer Foundation (MCF } \\
\text { rosis factor alpha; VEC }\end{array}$ & $\begin{array}{l}\text { ial cells; } \\
\text { a breast } \\
\text {-vascular }\end{array}$ \\
\hline
\end{tabular}

\subsection{Kallistatin Attenuates Defective Vascular Remodeling}

Vascular remodeling is a dynamic process that changes the structure of blood vessels to maintain a healthy state however in excess it contributes to AAA formation. Over activation of several cellular activities including apoptosis, proliferation, migration and degradation of the extracellular matrix contribute to excess vascular remodeling [115]. TNF- $\alpha$ is involved in all these four processes through inducing production of VEGF, interleukins, cellular adhesion molecules and MMPs. The ability of kallistatin to inhibit TNF- $\alpha$ and thereby limit angiogenesis, apoptosis, oxidative stress, inflammation, and cell proliferation and migration may ameliorate defective vascular remodeling and may play a protective role in vascular disorders, such as AAA. Kallistatin was originally shown to inhibit kallikrein and thereby limit kinin formation [17,18]. Kinins have been implicated in AAA formation within rodent models. Kinin B2 receptor blockade has been reported to protect against AAA development, growth and rupture in a mouse model, as well as reducing MMP secretion from human AAA explant in vitro [116]. Kinin B2 receptor blockade also limited neutrophil activation and development of an inflammatory phenotype in VSMCs in vitro. The inhibitory effect of kallistatin on tissue kallikrein would be expected to limit kinin generation and thereby antagonize the pro-aneurysmal effects of the kallikrein-kinin pathway. However, there is evidence suggesting that kallistatin also increases MMP-2 activity in human endo-PCs through enhancing NO and VEGF levels by activating PI3K-Akt signaling [44]. Although this may facilitate vascular repair and regeneration through promoting migration of endo-PCs. MMP-2 activity also contributes to medial matrix degradation in AAAs and possibly even rupture [9]. Thus, the protective role of kallistatin in maintaining positive vascular remodeling remains to be investigated further in pre-clinical AAA models.

\section{Conclusions}

In summary, AAA is a vascular disorder that is characterized by inflammation, apoptosis and extracellular matrix degradation. This review illustrates the potential of kallistatin in suppressing 
AAA development through attenuating a wide range of pathological mechanisms (Figure 4) including VEGF induced angiogenesis and inflammation, oxidative stress induced angiogenesis and apoptosis, TNF- $\alpha$ induced inflammation, apoptosis and MMPs production, as well as Wnt canonical signaling induced angiogenesis and inflammation. Direct studies examining the role of kallistatin in AAA are warranted and also should assess the potential beneficial effect of kallistatin. Since kallistatin has a range of actions, some of which may be detrimental, as well as beneficial, future studies should consider both systemic and local upregulation of kallistatin. Achieving elevated kallistatin levels through recombinant protein delivery and transgenic overexpressing methods has been reported to reduce blood pressure in animal models $[19,31,117]$, which could be beneficial in treating AAA patients. However, this warrants further preclinical studies using established AAA models.

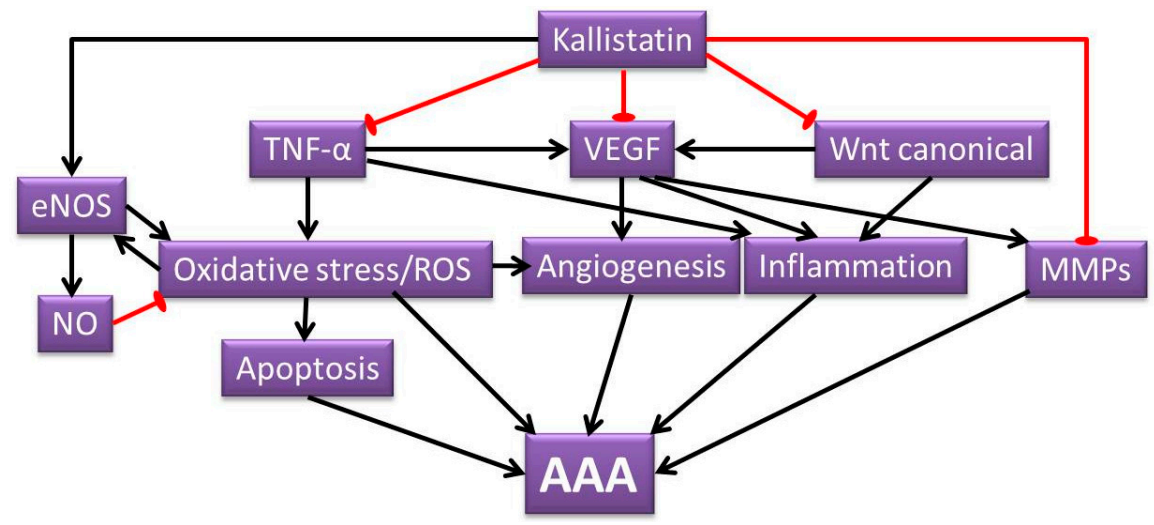

Figure 4. Illustration of postulated mechanisms of kallistatin attenuating AAA. Kallistatin has the potential of inhibiting various mechanisms that contribute to AAA formation. The pathological processes that are attenuated by kallistatin include oxidative stress, ROS signaling, apoptosis, angiogenesis, inflammation and MMP activity. The proposed AAA protective role of kallistatin are through its ability to inhibit various pathways, such as TNF- $\alpha$, VEGF and Wnt canonical signaling pathways, as well as kallistatin's ability to increase NO production through eNOS. The black arrow lines indicate promotional activity; the red stop lines indicate inhibiting activity.

Acknowledgments: This work is funded in part by grants from the National Health and Medical Research Council (1079369, 1098717), the Queensland Government, the Townsville Hospital Private Practice Trust, the Research Infrastructure Block Grant, and the Medicine Incentive Grant, College of Medicine, James Cook University (JCU-QLD-547271). Jonathan Golledge holds a Practitioner Fellowship from the National Health and Medical Research Council, Australia (1019921) and a Senior Clinical Research Fellowship from the Queensland Government. The funding bodies played no role in generation of the data presented in this publication.

Author Contributions: Jiaze Li designed the review and did the literature search, was responsible for figures and tables preparation and writing the manuscript; Smriti Murali Krishna contributed to manuscript preparation and revision; Jonathan Golledge contributed to manuscript preparation and critically revised the manuscript.

Conflicts of Interest: The authors confirm that there are no known conflicts of interest associated with this publication and there has been financial support for this work as noted above from external grants.

\section{Abbreviation}

$\begin{array}{ll}\text { AAA } & \text { abdominal aortic aneurysm } \\ \text { eNOS } & \text { endothelial nitric oxide synthase } \\ \text { MMPs } & \text { matrix metalloproteinases } \\ \text { NO } & \text { nitric oxide } \\ \text { ROS } & \text { reactive oxygen species } \\ \text { TNF- } \alpha & \text { tumor necrosis factor alpha } \\ \text { VEGF } & \text { vascular endothelial growth factor }\end{array}$




\section{References}

1. Sakalihasan, N.; Limet, R.; Defawe, O.D. Abdominal aortic aneurysm. Lancet 2005, 365, 1577-1589. [CrossRef]

2. Moxon, J.V.; Parr, A.; Emeto, T.I.; Walker, P.; Norman, P.E.; Golledge, J. Diagnosis and monitoring of abdominal aortic aneurysm: Current status and future prospects. Curr. Probl. Cardiol. 2010, 35, 512-548. [CrossRef] [PubMed]

3. Gillum, R.F. Epidemiology of aortic aneurysm in the united states. J. Clin. Epidemiol. 1995, 48, 1289-1298. [CrossRef]

4. Kniemeyer, H.W.; Kessler, T.; Reber, P.U.; Ris, H.B.; Hakki, H.; Widmer, M.K. Treatment of ruptured abdominal aortic aneurysm, a permanent challenge or a waste of resources? Prediction of outcome using a multi-organ-dysfunction score. Eur. J. Vasc. Endovasc. Surg. 2000, 19, 190-196. [CrossRef] [PubMed]

5. The UK small aneurysm trial participants. Mortality results for randomised controlled trial of early elective surgery or ultrasonographic surveillance for small abdominal aortic aneurysms. Lancet 1998, 352, 1649-1655.

6. Melrose, J.; Whitelock, J.; Xu, Q.; Ghosh, P. Pathogenesis of abdominal aortic aneurysms: Possible role of differential production of proteoglycans by smooth muscle cells. J. Vasc. Surg. 1998, 28, 676-686. [CrossRef]

7. Baxter, B.T.; McGee, G.S.; Shively, V.P.; Drummond, I.A.; Dixit, S.N.; Yamauchi, M.; Pearce, W.H. Elastin content, cross-links, and mrna in normal and aneurysmal human aorta. J. Vasc. Surg. 1992, 16, 192-200. [CrossRef]

8. Sakalihasan, N.; Heyeres, A.; Nusgens, B.V.; Limet, R.; Lapiere, C.M. Modifications of the extracellular matrix of aneurysmal abdominal aortas as a function of their size. Eur. J. Vasc. Surg. 1993, 7, 633-637. [CrossRef]

9. Hellenthal, F.A.; Buurman, W.A.; Wodzig, W.K.; Schurink, G.W. Biomarkers of AAA progression. Part 1: Extracellular matrix degeneration. Nat. Rev. Cardiol. 2009, 6, 464-474. [CrossRef] [PubMed]

10. Koch, A.E.; Kunkel, S.L.; Pearce, W.H.; Shah, M.R.; Parikh, D.; Evanoff, H.L.; Haines, G.K.; Burdick, M.D.; Strieter, R.M. Enhanced production of the chemotactic cytokines interleukin- 8 and monocyte chemoattractant protein-1 in human abdominal aortic aneurysms. Am. J. Pathol. 1993, 142, 1423-1431. [PubMed]

11. Newman, K.M.; Jean-Claude, J.; Li, H.; Ramey, W.G.; Tilson, M.D. Cytokines that activate proteolysis are increased in abdominal aortic aneurysms. Circulation 1994, 90, II224-II227. [PubMed]

12. Shah, P.K. Inflammation, metalloproteinases, and increased proteolysis: An emerging pathophysiological paradigm in aortic aneurysm. Circulation 1997, 96, 2115-2117. [CrossRef] [PubMed]

13. Walton, L.J.; Franklin, I.J.; Bayston, T.; Brown, L.C.; Greenhalgh, R.M.; Taylor, G.W.; Powell, J.T. Inhibition of prostaglandin e2 synthesis in abdominal aortic aneurysms: Implications for smooth muscle cell viability, inflammatory processes, and the expansion of abdominal aortic aneurysms. Circulation 1999, 100, 48-54. [CrossRef] [PubMed]

14. Jagadesham, V.P.; Scott, D.J.; Carding, S.R. Abdominal aortic aneurysms: An autoimmune disease? Trends Mol. Med. 2008, 14, 522-529. [CrossRef] [PubMed]

15. Choke, E.; Thompson, M.M.; Dawson, J.; Wilson, W.R.; Sayed, S.; Loftus, I.M.; Cockerill, G.W. Abdominal aortic aneurysm rupture is associated with increased medial neovascularization and overexpression of proangiogenic cytokines. Arterioscler. Thromb. Vasc. Biol. 2006, 26, 2077-2082. [CrossRef] [PubMed]

16. Guzik, B.; Sagan, A.; Ludew, D.; Mrowiecki, W.; Chwala, M.; Bujak-Gizycka, B.; Filip, G.; Grudzien, G.; Kapelak, B.; Zmudka, K.; et al. Mechanisms of oxidative stress in human aortic aneurysms-Association with clinical risk factors for atherosclerosis and disease severity. Int. J. Cardiol. 2013, 168, 2389-2396. [CrossRef] [PubMed]

17. Chao, J.; Schmaier, A.; Chen, L.M.; Yang, Z.; Chao, L. Kallistatin, a novel human tissue kallikrein inhibitor: Levels in body fluids, blood cells, and tissues in health and disease. J. Lab. Clin. Med. 1996, 127, 612-620. [CrossRef]

18. Chao, J.; Tillman, D.M.; Wang, M.Y.; Margolius, H.S.; Chao, L. Identification of a new tissue-kallikrein-binding protein. Biochem. J. 1986, 239, 325-331. [CrossRef] [PubMed]

19. Chao, J.; Stallone, J.N.; Liang, Y.M.; Chen, L.M.; Wang, D.Z.; Chao, L. Kallistatin is a potent new vasodilator. J. Clin. Investig. 1997, 100, 11-17. [CrossRef] [PubMed]

20. Wolf, W.C.; Harley, R.A.; Sluce, D.; Chao, L.; Chao, J. Localization and expression of tissue kallikrein and kallistatin in human blood vessels. J. Histochem. Cytochem. 1999, 47, 221-228. [CrossRef] [PubMed]

21. Ma, J.X.; King, L.P.; Yang, Z.; Crouch, R.K.; Chao, L.; Chao, J. Kallistatin in human ocular tissues: Reduced levels in vitreous fluids from patients with diabetic retinopathy. Curr. Eye Res. 1996, 15, 1117-1123. [CrossRef] [PubMed] 
22. Zhu, H.; Chao, J.; Kotak, I.; Guo, D.; Parikh, S.J.; Bhagatwala, J.; Dong, Y.; Patel, S.Y.; Houk, C.; Chao, L.; et al. Plasma kallistatin is associated with adiposity and cardiometabolic risk in apparently healthy african american adolescents. Metabolism 2013, 62, 642-646. [CrossRef] [PubMed]

23. Lu, S.L.; Tsai, C.Y.; Luo, Y.H.; Kuo, C.F.; Lin, W.C.; Chang, Y.T.; Wu, J.J.; Chuang, W.J.; Liu, C.C.; Chao, L.; et al. Kallistatin modulates immune cells and confers anti-inflammatory response to protect mice from group a streptococcal infection. Antimicrob. Agents Chemother. 2013, 57, 5366-5372. [CrossRef] [PubMed]

24. Yin, H.; Gao, L.; Shen, B.; Chao, L.; Chao, J. Kallistatin inhibits vascular inflammation by antagonizing tumor necrosis factor- $\alpha$-induced nuclear factor $\kappa \mathrm{B}$ activation. Hypertension 2010, 56, 260-267. [CrossRef] [PubMed]

25. Liu, Y.; Bledsoe, G.; Hagiwara, M.; Shen, B.; Chao, L.; Chao, J. Depletion of endogenous kallistatin exacerbates renal and cardiovascular oxidative stress, inflammation, and organ remodeling. Am. J. Physiol. Ren. Physiol. 2012, 303, F1230-F1238. [CrossRef] [PubMed]

26. Wang, C.R.; Chen, S.Y.; Wu, C.L.; Liu, M.F.; Jin, Y.T.; Chao, L.; Chao, J. Prophylactic adenovirus-mediated human kallistatin gene therapy suppresses rat arthritis by inhibiting angiogenesis and inflammation. Arthritis Rheumatol. 2005, 52, 1319-1324. [CrossRef] [PubMed]

27. Shen, B.; Gao, L.; Hsu, Y.T.; Bledsoe, G.; Hagiwara, M.; Chao, L.; Chao, J. Kallistatin attenuates endothelial apoptosis through inhibition of oxidative stress and activation of Akt-eNOS signaling. Am. J. Physiol. Heart Circ. Physiol. 2010, 299, H1419-H1427. [CrossRef] [PubMed]

28. Huang, K.F.; Huang, X.P.; Xiao, G.Q.; Yang, H.Y.; Lin, J.S.; Diao, Y. Kallistatin, a novel anti-angiogenesis agent, inhibits angiogenesis via inhibition of the NF-kB signaling pathway. Biomed. Pharmacother. 2014, 68, 455-461. [CrossRef] [PubMed]

29. Huang, K.F.; Yang, H.Y.; Xing, Y.M.; Lin, J.S.; Diao, Y. Recombinant human kallistatin inhibits angiogenesis by blocking VEGF signaling pathway. J. Cell. Biochem. 2014, 115, 575-584. [CrossRef] [PubMed]

30. Chen, L.M.; Chao, L.; Chao, J. Adenovirus-mediated delivery of human kallistatin gene reduces blood pressure of spontaneously hypertensive rats. Hum. Gene Ther. 1997, 8, 341-347. [CrossRef] [PubMed]

31. Chen, L.M.; Ma, J.; Liang, Y.M.; Chao, L.; Chao, J. Tissue kallikrein-binding protein reduces blood pressure in transgenic mice. J. Biol. Chem. 1996, 271, 27590-27594. [CrossRef] [PubMed]

32. Chen, V.C.; Chao, L.; Pimenta, D.C.; Bledsoe, G.; Juliano, L.; Chao, J. Identification of a major heparin-binding site in kallistatin. J. Biol. Chem. 2001, 276, 1276-1284. [CrossRef] [PubMed]

33. Miao, R.Q.; Agata, J.; Chao, L.; Chao, J. Kallistatin is a new inhibitor of angiogenesis and tumor growth. Blood 2002, 100, 3245-3252. [CrossRef] [PubMed]

34. Miao, R.Q.; Chen, V.; Chao, L.; Chao, J. Structural elements of kallistatin required for inhibition of angiogenesis. Am. J. Physiol. Cell Physiol. 2003, 284, C1604-C1613. [PubMed]

35. Watanabe, A.; Ichiki, T.; Sankoda, C.; Takahara, Y.; Ikeda, J.; Inoue, E.; Tokunou, T.; Kitamoto, S.; Sunagawa, K. Suppression of abdominal aortic aneurysm formation by inhibition of prolyl hydroxylase domain protein through attenuation of inflammation and extracellular matrix disruption. Clin. Sci. 2014, 126, 671-678. [CrossRef] [PubMed]

36. Wang, L.; Cheng, X.; Li, H.; Qiu, F.; Yang, N.; Wang, B.; Lu, H.; Wu, H.; Shen, Y.; Wang, Y.; et al. Quercetin reduces oxidative stress and inhibits activation of c-Jun N-terminal kinase/activator protein1 signaling in an experimental mouse model of abdominal aortic aneurysm. Mol. Med. Rep. 2014, 9, 435-442. [PubMed]

37. Emeto, T.I.; Moxon, J.V.; Au, M.; Golledge, J. Oxidative stress and abdominal aortic aneurysm: Potential treatment targets. Clin. Sci. 2016, 130, 301-315. [CrossRef] [PubMed]

38. Miwa, K.; Nakashima, H.; Aoki, M.; Miyake, T.; Kawasaki, T.; Iwai, M.; Oishi, M.; Kataoka, K.; Ohgi, S.; Ogihara, T.; et al. Inhibition of ets, an essential transcription factor for angiogenesis, to prevent the development of abdominal aortic aneurysm in a rat model. Gene Ther. 2005, 12, 1109-1118. [CrossRef] [PubMed]

39. Golledge, J.; Norman, P.E. Current status of medical management for abdominal aortic aneurysm. Atherosclerosis 2011, 217, 57-63. [CrossRef] [PubMed]

40. Golledge, A.L.; Walker, P.; Norman, P.E.; Golledge, J. A systematic review of studies examining inflammation associated cytokines in human abdominal aortic aneurysm samples. Dis. Mark. 2009, 26, 181-188. [CrossRef]

41. Grell, M.; Douni, E.; Wajant, H.; Lohden, M.; Clauss, M.; Maxeiner, B.; Georgopoulos, S.; Lesslauer, W.; Kollias, G.; Pfizenmaier, K.; et al. The transmembrane form of tumor necrosis factor is the prime activating ligand of the $80 \mathrm{kDa}$ tumor necrosis factor receptor. Cell 1995, 83, 793-802. [CrossRef] 
42. Wajant, H.; Pfizenmaier, K.; Scheurich, P. Tumor necrosis factor signaling. Cell Death Differ. 2003, 10, 45-65. [CrossRef] [PubMed]

43. Shen, B.; Smith, R.S., Jr.; Hsu, Y.T.; Chao, L.; Chao, J. Kruppel-like factor 4 is a novel mediator of kallistatin in inhibiting endothelial inflammation via increased endothelial nitric-oxide synthase expression. J. Biol. Chem. 2009, 284, 35471-35478. [CrossRef] [PubMed]

44. Gao, L.; Li, P.; Zhang, J.; Hagiwara, M.; Shen, B.; Bledsoe, G.; Chang, E.; Chao, L.; Chao, J. Novel role of kallistatin in vascular repair by promoting mobility, viability, and function of endothelial progenitor cells. J. Am. Heart Assoc. 2014, 3, e001194. [CrossRef] [PubMed]

45. Shen, B.; Hagiwara, M.; Yao, Y.Y.; Chao, L.; Chao, J. Salutary effect of kallistatin in salt-induced renal injury, inflammation, and fibrosis via antioxidative stress. Hypertension 2008, 51, 1358-1365. [CrossRef] [PubMed]

46. Ushio-Fukai, M. Redox signaling in angiogenesis: Role of nadph oxidase. Cardiovasc. Res. 2006, 71, $226-235$. [CrossRef] [PubMed]

47. Griendling, K.K.; Sorescu, D.; Ushio-Fukai, M. NAD(P)H oxidase: Role in cardiovascular biology and disease. Circ. Res. 2000, 86, 494-501. [CrossRef] [PubMed]

48. Ushio-Fukai, M.; Tang, Y.; Fukai, T.; Dikalov, S.I.; Ma, Y.; Fujimoto, M.; Quinn, M.T.; Pagano, P.J.; Johnson, C.; Alexander, R.W. Novel role of gp91 ${ }^{\text {phox }}$-containing NAD(P)H oxidase in vascular endothelial growth factor-induced signaling and angiogenesis. Circ. Res. 2002, 91, 1160-1167. [CrossRef] [PubMed]

49. Abid, M.R.; Spokes, K.C.; Shih, S.C.; Aird, W.C. Nadph oxidase activity selectively modulates vascular endothelial growth factor signaling pathways. J. Biol. Chem. 2007, 282, 35373-35385. [CrossRef] [PubMed]

50. Ushio-Fukai, M.; Alexander, R.W. Reactive oxygen species as mediators of angiogenesis signaling: Role of NAD(P)H oxidase. Mol. Cell. Biochem. 2004, 264, 85-97. [CrossRef] [PubMed]

51. Harfouche, R.; Malak, N.A.; Brandes, R.P.; Karsan, A.; Irani, K.; Hussain, S.N. Roles of reactive oxygen species in angiopoietin-1/tie-2 receptor signaling. FASEB J. 2005, 19, 1728-1730. [CrossRef] [PubMed]

52. Chao, C.; Madeddu, P.; Wang, C.; Liang, Y.; Chao, L.; Chao, J. Differential regulation of kallikrein, kininogen, and kallikrein-binding protein in arterial hypertensive rats. Am. J. Physiol. 1996, 271, F78-F86. [PubMed]

53. Shen, B.; Chao, L.; Chao, J. Pivotal role of JNK-dependent $\mathrm{FOXO}_{1}$ activation in downregulation of kallistatin expression by oxidative stress. Am. J. Physiol. Heart Circ. Physiol. 2010, 298, H1048-H1054. [CrossRef] [PubMed]

54. Gao, L.; Yin, H.; Smith, R.S.; Chao, L.; Chao, J. Role of kallistatin in prevention of cardiac remodeling after chronic myocardial infarction. Lab. Investig. 2008, 88, 1157-1166. [CrossRef] [PubMed]

55. Yiu, W.H.; Wong, D.W.; Wu, H.J.; Li, R.X.; Yam, I.; Chan, L.Y.; Leung, J.C.; Lan, H.Y.; Lai, K.N.; Tang, S.C. Kallistatin protects against diabetic nephropathy in $\mathrm{db} / \mathrm{db}$ mice by suppressing AGE-RAGE-induced oxidative stress. Kidney Int. 2015. [CrossRef] [PubMed]

56. Zhu, C.; Pan, F.; Ge, L.; Zhou, J.; Chen, L.; Zhou, T.; Zong, R.; Xiao, X.; Dong, N.; Yang, M.; et al. SERPINA3K plays antioxidant roles in cultured pterygial epithelial cells through regulating ROS system. PLoS ONE 2014, 9, e108859. [CrossRef] [PubMed]

57. Forstermann, U.; Munzel, T. Endothelial nitric oxide synthase in vascular disease: From marvel to menace. Circulation 2006, 113, 1708-1714. [CrossRef] [PubMed]

58. Wang, W.; Wang, S.; Yan, L.; Madara, P.; Del, P.C.A.; Wesley, R.A.; Danner, R.L. Superoxide production and reactive oxygen species signaling by endothelial nitric-oxide synthase. J. Biol. Chem. 2000, 275, 16899-16903. [CrossRef] [PubMed]

59. Chen, G.; Cao, P.; Goeddel, D.V. TNF-induced recruitment and activation of the IKK complex require Cdc37 and Hsp90. Mol. Cell 2002, 9, 401-410. [CrossRef]

60. Giraudo, E.; Primo, L.; Audero, E.; Gerber, H.P.; Koolwijk, P.; Soker, S.; Klagsbrun, M.; Ferrara, N.; Bussolino, F. Tumor necrosis factor- $\alpha$ regulates expression of vascular endothelial growth factor receptor-2 and of its co-receptor neuropilin-1 in human vascular endothelial cells. J. Biol. Chem. 1998, 273, 22128-22135. [CrossRef] [PubMed]

61. Guadagni, F.; Ferroni, P.; Palmirotta, R.; Portarena, I.; Formica, V.; Roselli, M. Review. TNF/VEGF cross-talk in chronic inflammation-related cancer initiation and progression: An early target in anticancer therapeutic strategy. In Vivo 2007, 21, 147-161. [PubMed]

62. Ristimaki, A.; Narko, K.; Enholm, B.; Joukov, V.; Alitalo, K. Proinflammatory cytokines regulate expression of the lymphatic endothelial mitogen vascular endothelial growth factor-C. J. Biol. Chem. 1998, 273, 8413-8418. [CrossRef] [PubMed] 
63. Sakurai, H.; Suzuki, S.; Kawasaki, N.; Nakano, H.; Okazaki, T.; Chino, A.; Doi, T.; Saiki, I. Tumor necrosis factor- $\alpha$-induced IKK phosphorylation of NF- KB p65 on serine 536 is mediated through the TRAF2, TRAF5, and TAK1 signaling pathway. J. Biol. Chem. 2003, 278, 36916-36923. [CrossRef] [PubMed]

64. Zarubin, T.; Han, J. Activation and signaling of the p38 MAP kinase pathway. Cell Res. 2005, 15, 11-18. [CrossRef] [PubMed]

65. Thompson, M.M.; Jones, L.; Nasim, A.; Sayers, R.D.; Bell, P.R. Angiogenesis in abdominal aortic aneurysms. Eur. J. Vasc. Endovasc. Surg. 1996, 11, 464-469. [CrossRef]

66. Majno, G. Chronic inflammation: Links with angiogenesis and wound healing. Am. J. Pathol. 1998, 153, 1035-1039. [CrossRef]

67. Carmeliet, P. Mechanisms of angiogenesis and arteriogenesis. Nat. Med. 2000, 6, 389-395. [CrossRef] [PubMed]

68. Bagli, E.; Xagorari, A.; Papetropoulos, A.; Murphy, C.; Fotsis, T. Angiogenesis in inflammation. Autoimmun. Rev. 2004, 3, S26. [PubMed]

69. Firestein, G.S. Starving the synovium: Angiogenesis and inflammation in rheumatoid arthritis. J. Clin. Investig. 1999, 103, 3-4. [CrossRef] [PubMed]

70. Szekanecz, Z.; Koch, A.E. Vascular endothelium and immune responses: Implications for inflammation and angiogenesis. Rheum. Dis. Clin. N. Am. 2004, 30, 97-114. [CrossRef]

71. Jackson, J.R.; Seed, M.P.; Kircher, C.H.; Willoughby, D.A.; Winkler, J.D. The codependence of angiogenesis and chronic inflammation. FASEB J. 1997, 11, 457-465. [PubMed]

72. Choke, E.; Cockerill, G.W.; Dawson, J.; Wilson, R.W.; Jones, A.; Loftus, I.M.; Thompson, M.M. Increased angiogenesis at the site of abdominal aortic aneurysm rupture. Ann. N. Y. Acad. Sci. 2006, 1085, 315-319. [CrossRef] [PubMed]

73. Carmeliet, P. Angiogenesis in life, disease and medicine. Nature 2005, 438, 932-936. [CrossRef] [PubMed]

74. Ferrara, N.; Gerber, H.P.; LeCouter, J. The biology of vegf and its receptors. Nat. Med. 2003, 9, 669-676. [CrossRef] [PubMed]

75. Dvorak, H.F.; Detmar, M.; Claffey, K.P.; Nagy, J.A.; van de Water, L.; Senger, D.R. Vascular permeability factor/vascular endothelial growth factor: An important mediator of angiogenesis in malignancy and inflammation. Int. Arch. Allergy Immunol. 1995, 107, 233-235. [CrossRef] [PubMed]

76. Lee, Y.C. The involvement of VEGF in endothelial permeability: A target for anti-inflammatory therapy. Curr. Opin. Investig. Drugs 2005, 6, 1124-1130. [PubMed]

77. Taimeh, Z.; Loughran, J.; Birks, E.J.; Bolli, R. Vascular endothelial growth factor in heart failure. Nat. Rev. Cardiol. 2013, 10, 519-530. [CrossRef] [PubMed]

78. Abid, M.R.; Tsai, J.C.; Spokes, K.C.; Deshpande, S.S.; Irani, K.; Aird, W.C. Vascular endothelial growth factor induces manganese-superoxide dismutase expression in endothelial cells by a Rac1-regulated NADPH oxidase-dependent mechanism. FASEB J. 2001, 15, 2548-2550. [CrossRef] [PubMed]

79. Chiarugi, P.; Cirri, P. Redox regulation of protein tyrosine phosphatases during receptor tyrosine kinase signal transduction. Trends Biochem. Sci. 2003, 28, 509-514. [CrossRef]

80. Colavitti, R.; Pani, G.; Bedogni, B.; Anzevino, R.; Borrello, S.; Waltenberger, J.; Galeotti, T. Reactive oxygen species as downstream mediators of angiogenic signaling by vascular endothelial growth factor receptor-2/KDR. J. Biol. Chem. 2002, 277, 3101-3108. [CrossRef] [PubMed]

81. Dimmeler, S.; Fleming, I.; Fisslthaler, B.; Hermann, C.; Busse, R.; Zeiher, A.M. Activation of nitric oxide synthase in endothelial cells by Akt-dependent phosphorylation. Nature 1999, 399, 601-605. [PubMed]

82. Downward, J. Mechanisms and consequences of activation of protein kinase B/Akt. Curr. Opin. Cell Biol. 1998, 10, 262-267. [CrossRef]

83. Fulton, D.; Gratton, J.P.; McCabe, T.J.; Fontana, J.; Fujio, Y.; Walsh, K.; Franke, T.F.; Papapetropoulos, A.; Sessa, W.C. Regulation of endothelium-derived nitric oxide production by the protein kinase Akt. Nature 1999, 399, 597-601. [PubMed]

84. Gee, E.; Milkiewicz, M.; Haas, T.L. P38 MAPK activity is stimulated by vascular endothelial growth factor receptor 2 activation and is essential for shear stress-induced angiogenesis. J. Cell. Physiol. 2010, 222, 120-126. [CrossRef] [PubMed]

85. Gerber, H.P.; McMurtrey, A.; Kowalski, J.; Yan, M.; Keyt, B.A.; Dixit, V.; Ferrara, N. Vascular endothelial growth factor regulates endothelial cell survival through the phosphatidylinositol 3'-kinase/Akt signal transduction pathway. J. Biol. Chem. 1998, 273, 30336-30343. [CrossRef] [PubMed] 
86. Hemmings, B.A. Akt signaling: Linking membrane events to life and death decisions. Science 1997, 275, 628-630. [CrossRef] [PubMed]

87. Huang, L.; Sankar, S.; Lin, C.; Kontos, C.D.; Schroff, A.D.; Cha, E.H.; Feng, S.M.; Li, S.F.; Yu, Z.; van Etten, R.L.; et al. HCPTPA, a protein tyrosine phosphatase that regulates vascular endothelial growth factor receptor-mediated signal transduction and biological activity. J. Biol. Chem. 1999, 274, 38183-38188. [CrossRef] [PubMed]

88. Kim, I.; Moon, S.O.; Kim, S.H.; Kim, H.J.; Koh, Y.S.; Koh, G.Y. Vascular endothelial growth factor expression of intercellular adhesion molecule 1 (ICAM-1), vascular cell adhesion molecule 1 (VCAM-1), and E-selectin through nuclear factor-kappa b activation in endothelial cells. J. Biol. Chem. 2001, 276, 7614-7620. [CrossRef] [PubMed]

89. Lambeth, J.D.; Cheng, G.; Arnold, R.S.; Edens, W.A. Novel homologs of gp91phox. Trends Biochem. Sci. 2000, 25, 459-461. [CrossRef]

90. Lamers, J.M.; de Jonge, H.W.; Panagia, V.; van Heugten, H.A. Receptor-mediated signalling pathways acting through hydrolysis of membrane phospholipids in cardiomyocytes. Cardioscience 1993, 4, 121-131. [PubMed]

91. Lassegue, B.; Clempus, R.E. Vascular NAD(P)H oxidases: Specific features, expression, and regulation. Am. J. Physiol. Regul. Integr. Comp. Physiol. 2003, 285, R277-R297. [CrossRef] [PubMed]

92. Lin, M.T.; Yen, M.L.; Lin, C.Y.; Kuo, M.L. Inhibition of vascular endothelial growth factor-induced angiogenesis by resveratrol through interruption of Src-dependent vascular endothelial cadherin tyrosine phosphorylation. Mol. Pharmacol. 2003, 64, 1029-1036. [CrossRef] [PubMed]

93. Marumo, T.; Schini-Kerth, V.B.; Busse, R. Vascular endothelial growth factor activates nuclear factor- $\mathrm{kB}$ and induces monocyte chemoattractant protein-1 in bovine retinal endothelial cells. Diabetes 1999, 48, 1131-1137. [CrossRef] [PubMed]

94. Meng, D.; Mei, A.; Liu, J.; Kang, X.; Shi, X.; Qian, R.; Chen, S. Nadph oxidase 4 mediates insulin-stimulated HIF-1 $\alpha$ and VEGF expression, and angiogenesis in vitro. PLoS ONE 2012, 7, e48393. [CrossRef] [PubMed]

95. Rottbauer, W.; Just, S.; Wessels, G.; Trano, N.; Most, P.; Katus, H.A.; Fishman, M.C. VEGF-PLC $\gamma 1$ pathway controls cardiac contractility in the embryonic heart. Genes Dev. 2005, 19, 1624-1634. [CrossRef] [PubMed]

96. Rousseau, S.; Houle, F.; Landry, J.; Huot, J. P38 MAP kinase activation by vascular endothelial growth factor mediates actin reorganization and cell migration in human endothelial cells. Oncogene 1997, 15, 2169-2177. [CrossRef] [PubMed]

97. Shiojima, I.; Walsh, K. Role of Akt signaling in vascular homeostasis and angiogenesis. Circ. Res. 2002, 90, 1243-1250. [CrossRef] [PubMed]

98. Yamaoka-Tojo, M.; Ushio-Fukai, M.; Hilenski, L.; Dikalov, S.I.; Chen, Y.E.; Tojo, T.; Fukai, T.; Fujimoto, M.; Patrushev, N.A.; Wang, N.; et al. IQGAP1, a novel vascular endothelial growth factor receptor binding protein, is involved in reactive oxygen species-Dependent endothelial migration and proliferation. Circ. Res. 2004, 95, 276-283. [CrossRef] [PubMed]

99. Zhang, Q.; Yu, C.; Peng, S.; Xu, H.; Wright, E.; Zhang, X.; Huo, X.; Cheng, E.; Pham, T.H.; Asanuma, K.; et al. Autocrine VEGF signaling promotes proliferation of neoplastic barrett's epithelial cells through a PLC-dependent pathway. Gastroenterology 2014, 146, 461-472. [CrossRef] [PubMed]

100. Reis, M.; Liebner, S. Wnt signaling in the vasculature. Exp. Cell Res. 2013, 319, 1317-1323. [CrossRef] [PubMed]

101. Ju, R.; Cirone, P.; Lin, S.; Griesbach, H.; Slusarski, D.C.; Crews, C.M. Activation of the planar cell polarity formin daam1 leads to inhibition of endothelial cell proliferation, migration, and angiogenesis. Proc. Natl. Acad. Sci. USA 2010, 107, 6906-6911. [CrossRef] [PubMed]

102. Klaus, A.; Birchmeier, W. Wnt signalling and its impact on development and cancer. Nat. Rev. Cancer 2008, 8, 387-398. [CrossRef] [PubMed]

103. Kobayashi, Y. Roles of Wnt signaling in bone metabolism. Clin. Calcium 2012, 22, 1701-1706. [PubMed]

104. Liebner, S.; Plate, K.H. Differentiation of the brain vasculature: The answer came blowing by the Wnt. J. Angiogenes Res. 2010, 2, 1. [CrossRef] [PubMed]

105. Liu, X.; Zhang, B.; McBride, J.D.; Zhou, K.; Lee, K.; Zhou, Y.; Liu, Z.; Ma, J.X. Antiangiogenic and antineuroinflammatory effects of kallistatin through interactions with the canonical Wnt pathway. Diabetes 2013, 62, 4228-4238. [CrossRef] [PubMed]

106. Maeda, K.; Takahashi, N.; Kobayashi, Y. Roles of Wnt signals in bone resorption during physiological and pathological states. J. Mol. Med. (Berl.) 2013, 91, 15-23. [CrossRef] [PubMed] 
107. Nilsson, L.M.; Nilsson-Ohman, J.; Zetterqvist, A.V.; Gomez, M.F. Nuclear factor of activated T-cells transcription factors in the vasculature: The good guys or the bad guys? Curr. Opin. Lipidol. 2008, 19, 483-490. [CrossRef] [PubMed]

108. Ravindranath, A.; Yuen, H.F.; Chan, K.K.; Grills, C.; Fennell, D.A.; Lappin, T.R.; El-Tanani, M. Wnt- $\beta$-catenin-Tcf-4 signalling-modulated invasiveness is dependent on osteopontin expression in breast cancer. Br. J. Cancer 2011, 105, 542-551. [CrossRef] [PubMed]

109. Niehrs, C. Function and biological roles of the Dickkopf family of Wnt modulators. Oncogene 2006, 25, 7469-7481. [CrossRef] [PubMed]

110. Zhang, J.; Yang, Z.; Li, P.; Bledsoe, G.; Chao, L.; Chao, J. Kallistatin antagonizes Wnt/ $\beta$-catenin signaling and cancer cell motility via binding to low-density lipoprotein receptor-related protein 6. Mol. Cell. Biochem. 2013, 379, 295-301. [CrossRef] [PubMed]

111. McBride, J.D.; Jenkins, A.J.; Liu, X.; Zhang, B.; Lee, K.; Berry, W.L.; Janknecht, R.; Griffin, C.T.; Aston, C.E.; Lyons, T.J.; et al. Elevated circulation levels of an antiangiogenic serpin in patients with diabetic microvascular complications impair wound healing through suppression of Wnt signaling. J. Investig. Dermatol. 2014, 134, 1725-1734. [CrossRef] [PubMed]

112. Gao, G.; Shao, C.; Zhang, S.X.; Dudley, A.; Fant, J.; Ma, J.X. Kallikrein-binding protein inhibits retinal neovascularization and decreases vascular leakage. Diabetologia 2003, 46, 689-698. [PubMed]

113. Liu, X.; McBride, J.; Zhou, Y.; Liu, Z.; Ma, J.X. Regulation of endothelial progenitor cell release by Wnt signaling in bone marrow. Investig. Ophthalmol. Vis. Sci. 2013, 54, 7386-7394. [CrossRef] [PubMed]

114. Phng, L.K.; Gerhardt, H. Angiogenesis: A team effort coordinated by notch. Dev. Cell 2009, 16, $196-208$. [CrossRef] [PubMed]

115. Renna, N.F.; de Las Heras, N.; Miatello, R.M. Pathophysiology of vascular remodeling in hypertension. Int. J. Hypertens. 2013, 2013, 808353. [CrossRef] [PubMed]

116. Moran, C.S.; Rush, C.M.; Dougan, T.; Jose, R.J.; Biros, E.; Norman, P.E.; Gera, L.; Golledge, J. Modulation of kinin $\mathrm{B} 2$ receptor signaling controls aortic dilatation and rupture in the angiotensin II-infused apolipoprotein E-deficient mouse. Arterioscler. Thromb. Vasc. Biol. 2016, 36, 898-907. [CrossRef] [PubMed]

117. Chao, J.; Chao, L. Kallistatin in blood pressure regulation transgenic and somatic gene delivery studies. Trends Cardiovasc. Med. 1997, 7, 307-311. [CrossRef] 